\title{
Experimental investigations of spontaneous damage to wet multi-plate clutches with carbon friction linings
}

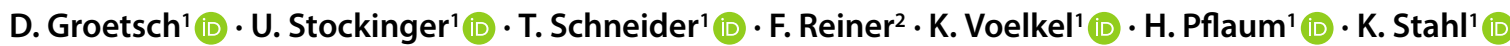

Received: 28 September 2020 / Accepted: 6 May 2021 / Published online: 9 June 2021

(c) The Author(s) 2021

\begin{abstract}
Safety and comfort, while ensuring torque transfer capability, are essential for wet multi-plate clutches. The safety of the torque transmission process largely depends on the endurance of the tribological system against spontaneous and long-term damages. Modern Carbon friction linings in wet multi-plate clutch applications offer superior wear resistance compared to other friction materials, but there is hardly any published data on their spontaneous damage behavior. This article therefore presents results from experimental studies on the spontaneous damage of innovative Carbon friction linings carried out on a component test rig. Furthermore, the influence of different steel plate thicknesses $(3.5 \mathrm{~mm}$ vs. $6 \mathrm{~mm})$ was investigated. 16 step tests, including visual assessments of the clutches, were performed with Carbon-fiber reinforced plastic (CFRP) and Carbon-fiber reinforced Carbon $(\mathrm{C} / \mathrm{C})$ linings in brake operations.

The results of the step tests are documented in friction work over friction power diagrams. Results show excellent endurance of modern Carbon friction linings against spontaneous damage and thus makes them suitable for safety relevant high-performance applications. There was no clear influence of the steel plate thickness on spontaneous damage. However, the $\mathrm{C} / \mathrm{C}$ friction lining ran at a specific energy of up to $5.26 \mathrm{~J} / \mathrm{mm}^{2}$ in combination with sliding velocities of up to $67 \mathrm{~m} / \mathrm{s}$ (high speed application) without failure. This is the highest published spontaneous damage resistance identified for wet clutches.
\end{abstract}

\author{
D. Groetsch \\ groetsch@fzg.mw.tum.de \\ U. Stockinger \\ stockinger@fzg.mw.tum.de \\ T. Schneider \\ schneider@fzg.mw.tum.de \\ F. Reiner \\ Florian.Reiner@sglcarbon.com \\ K. Voelkel \\ voelkel@ fzg.mw.tum.de
}

H. Pflaum

pflaum@fzg.mw.tum.de

K. Stahl

fzg@fzg.mw.tum.de

1 Forschungsstelle für Zahnräder und Getriebebau - FZG, TU München, Boltzmannstraße 15, 85748 Garching bei München, Germany

2 SGL Technologies GmbH, Werner-von-Siemens-Straße 18, 86405 Meitingen, Germany 


\section{Experimentelle Untersuchungen zum Spontanschädigungsverhalten nasslaufender Lamellenkupplungen mit Carbon-Reibbelägen}

\section{Zusammenfassung}

Die Gewährleistung von Sicherheit und Komfort bei gleichzeitiger Bereitstellung der Drehmomentübertragungsfähigkeit ist bei nassen Lamellenkupplungen unerlässlich. Die Sicherheit der Drehmomentübertragung wird dabei maßgeblich von der Widerstandsfähigkeit des tribologischen Systems gegenüber Spontan- und Dauerbelastungsschäden beeinflusst. Moderne Carbon-Reibbeläge in nassen Lamellenkupplungen bieten im Vergleich zu anderen Reibmaterialien eine hohe Verschleißfestigkeit, jedoch gibt es kaum veröffentlichte Daten zum Spontanschädigungsverhalten. In diesem Beitrag werden experimentelle Ergebnisse aus Untersuchungen am Komponentenprüfstand zur Spontanschädigung innovativer Carbon-Reibbeläge vorgestellt. In den Versuchen wurde u.a. der Einfluss unterschiedlicher Stahllamellendicken (3,5 mm vs. 6 $\mathrm{mm}$ ) untersucht. Es wurden 16 Stufentests, inklusive visueller Beurteilung der Kupplungen, mit CFK- und CFC-Belägen im Bremsbetrieb durchgeführt. Die Ergebnisse der Stufentests sind in Reibarbeit über Reibleistungs Diagrammen dokumentiert. Die untersuchten Carbon-Reibbeläge zeigen eine hohe Widerstandsfähigkeit gegenüber Spontanschäden und sind somit für die Verwendung in sicherheitsrelevanten Hochleistungsanwendungen geeignet. Die Ergebnisse zeigen keinen eindeutigen Einfluss der Stahllamellendicke auf das Spontanschädigungsverhalten. Der untersuchte CFC-Reibbelag konnte jedoch bis zu einer spezifischen Reibarbeit von $5,26 \mathrm{~J} / \mathrm{mm}^{2}$ in Kombination mit Gleitgeschwindigkeiten von bis zu $67 \mathrm{~m} / \mathrm{s}$ (Hochgeschwindigkeitsanwendung) ohne Ausfall betrieben werden. Dies ist aktuell die höchste veröffentlichte Widerstandsfähigkeit gegenüber Spontanschäden bei nassen Lamellenkupplungen.

\section{Introduction}

Wet multi-plate clutches and brakes are widely used in vehicle transmissions and industrial applications and usually fulfill safety- and comfort-relevant functions. Increasing performance requirements and growing cost pressure require continuous improvements of design and operational safety. These market trends have triggered the need to develop new friction materials in addition to established solutions such as powder metallurgical and paper-based friction linings. Paper-based materials cover a broad spectrum of clutch applications, while Carbon-based materials have been introduced in high-end applications.

Multi-plate clutches are often used in safety-relevant applications and therefore operativeness and reliability without damage must be ensured, even under high loads or in individual overload situations. Damage of wet multi-plate clutches can originate from high mechanical and/or thermal loads and can be subdivided into spontaneous and long-term damages [1].

Fiber reinforced composites are widely used in many applications in the field of automotive and aircraft manufacturing [2]. Besides their superior strength properties for structural applications, they also show great tribological properties under high loads and superior weight to strength ratios compared to other composites in similar applications [2, 3]. Rank [4] divides Carbon friction linings for wet multi-plate clutches into four groups:

Woven Carbon fiber reinforced Carbon $(\mathrm{C} / \mathrm{C})$, paperbased friction linings reinforced with Carbon fibers and particles (composite Carbon [5]), woven Carbon fiber reinforced plastic (CFRP) and two ply Carbon friction linings.
Several studies show that the use of Carbon fibers in composites results in a lower coefficient of friction and increases the risk of shudder (self-induced vibration), especially at high temperatures [6-9]. The use of Carbon and PAN (polyacrylonitrile) fibers, on the other hand, makes friction composites less sensitive to dynamic fluctuations in brake pressure and sliding speed $[10,11]$. According to Kearsey and Wagner [11], the influence of additives on the friction behavior of Carbon friction surfaces is comparable to that of paper friction linings, but less pronounced, which is confirmed by Stockinger et al. [12].

Cheng [13] investigates the influence of resin impregnation levels on the surface roughness. At low resin impregnation levels, the surface is rougher and the coefficient of friction is higher. The surface also becomes rougher with increasing fiber length [14]. Wu [15] and Zhang [16] describe a strong dependence of the coefficient of friction on the resin type. Numerous publications report an increase in the wear resistance $[17,18]$ and the coefficient of friction [18] of Carbon friction linings by introducing nanotubes into the resin material. The dynamic friction coefficient, friction stability, braking stability, thermal stability and wear resistance of the specimens with nanotubes are better than the specimens without nanotubes $[19,20]$.

The wear resistance of Carbon friction linings is higher than that of paper friction linings $[4,7,11,21-25]$. The combination of adhesive wear, abrasive wear and thermal degradation is considered to be the main wear mechanism in wet Carbon friction plates over their entire service life [8]. With low resin content, the dominant wear mechanisms are microcutting, breakage and removal of Carbon fibers. For friction materials with a high resin content, decompo- 

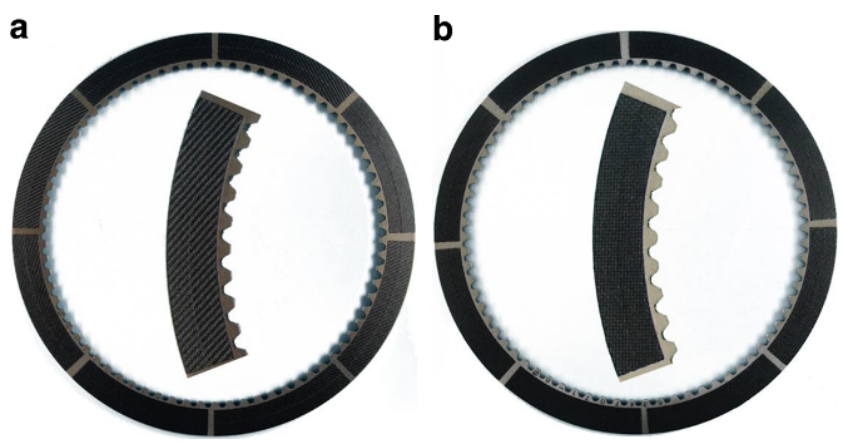

Fig. 1 Friction Plate (CFRP (a), C/C (b)) [40]

sition of the matrix is the dominant wear mechanism [8, 21]. By pretreating the fibers with nitric acid [18] or $\mathrm{SiO}_{2}$ thin film [16], the wear resistance of the Carbon friction material can be increased. Su et al. and Wang et al. [17, 26] show a strongly increased adhesive wear at higher friction surface temperatures. For organic Carbon friction linings in synchronizers, the surface smoothes under high thermal loads, because oil crack products block the friction linings' pores and reduce surface roughness [27, 28]. This decreases the $\mathrm{CoF}$ at high sliding speeds. This failure mechanism is observed for paper friction materials in wet clutches as well $[29,30]$. A polymer matrix with excellent heat resistance enables safer and more comfortable shifting operations and extends the service life of a Carbon-based wet clutch [8]. The thermal conductivity of the friction material can be increased by incorporating Carbon fiber in a composite material $[11,24]$.

In addition to long-term mechanisms like wear, hot spots (spontaneous damage) also occur at high temperatures in organic friction systems [31]. Hämmerl [32] describes hot spots as irregular yellow-brown to bluish discoloration on steel plates. Anderson and Knapp [33], Fairbank et al. [34] and Schneider et al. [35] report two different types of hot

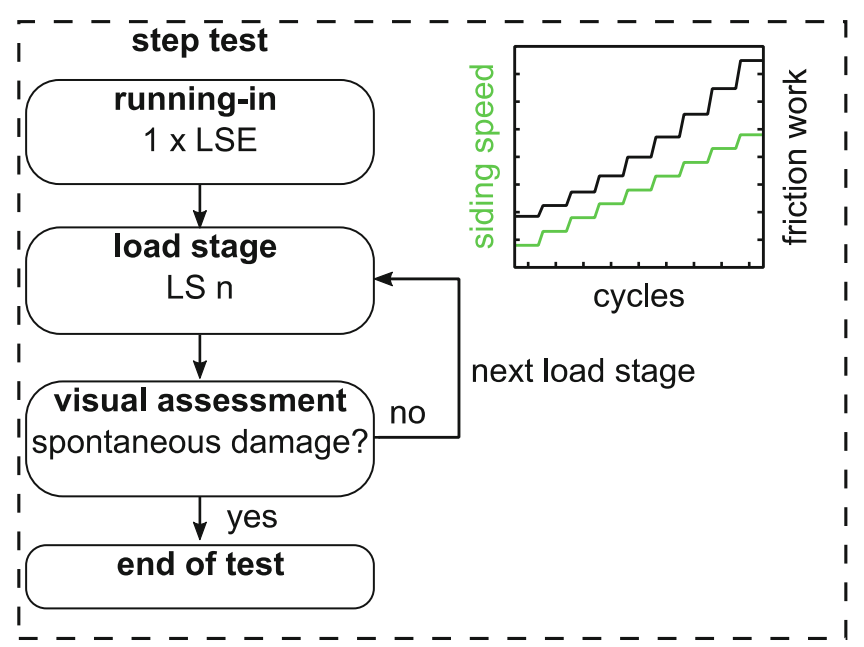

Fig. 2 Test procedure step test

spots. In the first stage, only "cosmetic" changes of the surface are observed, whereas plastic deformations on the steel friction interfaces can be observed in the second stage. In the second stage, local martensite formation occurs, which indicates very high local temperatures of up to $900{ }^{\circ} \mathrm{C}$. In addition to influencing the material structure, Kasem et al. [31] also observe plastic deformations of the surface in areas affected by hot spots, which they attribute to a melting of the steel material due to the high temperatures, coupled with high mechanical stresses. The effect of plastic deformation under frictional stress is reported as "tribological transformation of surface-TTS" by Eleöd et al. [36] and "tribological surface transformation-TST" by Antoni [37] and Antoni et al. [38]. Lam et al. [39] show that Carbon friction linings are less sensitive to hot spot formations than paper friction linings. These results are confirmed by Kearsey and Wagner [11], who compare the load carrying
Fig. 3 Deterioration classification in friction work/friction power diagram in comparison with a picture of visual assessment and measured signals $(\mu$, n)

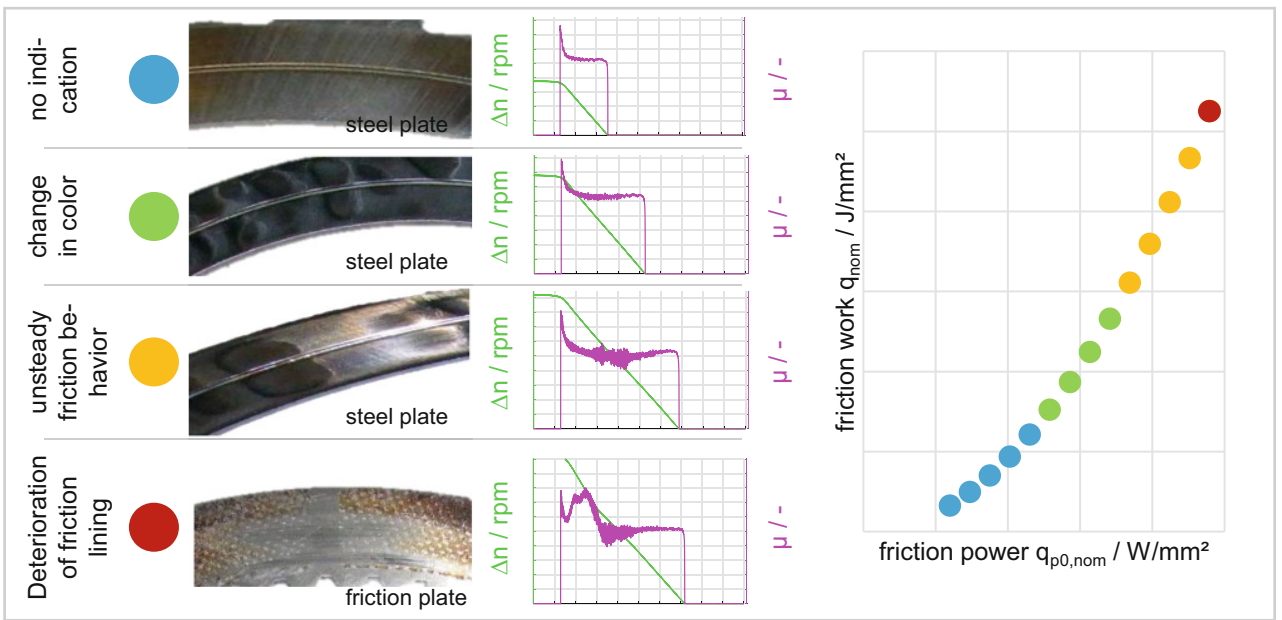


Table 1 Technical data of lubricant

\begin{tabular}{lll}
\hline & $\begin{array}{l}\text { Kinematic viscosity at } \\
40^{\circ} \mathrm{C}\end{array}$ & $\begin{array}{l}\text { Kinematic viscosity at } \\
100^{\circ} \mathrm{C}\end{array}$ \\
\hline $\begin{array}{l}\text { Engine } \\
\text { oil }\end{array}$ & $52 \mathrm{~mm}^{2} / \mathrm{s}$ & $11 \mathrm{~mm}^{2} / \mathrm{s}$ \\
\hline
\end{tabular}

capacity with regard to hot spots of Carbon friction systems and paper friction systems.

The friction behavior of wet multi-plate clutches with Carbon friction linings has been discussed widely [12, 25, 40]. Only few publications focus on spontaneous damage behavior of Carbon plates [11]. This paper extends the knowledge through experimental investigations of spontaneous damage of two different Carbon friction materials (CFRP and C/C). Furthermore, two different steel plate thicknesses are analyzed.

\section{Method}

We investigated spontaneous damage behavior of four variants of a wet clutch during brake operations.

\subsection{Test rig-parts and lubricant}

All tests were carried out on the ZF/FZG KLP-260 wet brake component test rig. Details on the capabilities of the test rig and classification of measurement accuracy are stated in prior publications [40, 41]. For the experiments, we used steel plates (outer plates) from serial production of an industrial application. The friction plates (inner plates) are prototype parts. Fig. 1 shows the multi-segmented groove pattern of the inner plates for both friction materials (CFRP, $\mathrm{C} / \mathrm{C})$.

We used a new clutch package with four friction interfaces for each test. The mean radius was $r_{m}=123 \mathrm{~mm}$ and the clearance between each friction interface was $0.20 \mathrm{~mm}$. The thicknesses of the steel plates were $3.5 \mathrm{~mm}$ and $6.0 \mathrm{~mm}$. The $6.0 \mathrm{~mm}$ steel plates should reduce operating temperatures due to higher thermal mass of the plates. This resulted in a total of four clutch variants for the experimental investigations.

The temperature of the inner steel plate (axial position approx. midplane/drill depth approx. mean radius) was measured with a thermocouple (NiCrNi Typ K Class 1, $\varnothing 0.5 \mathrm{~mm}$, response time approx. $30 \mathrm{~ms}$ calculated acc. to [42]).

Table 1 summarizes the technical data of the lubricant from serial production that was used for all tests. The engine oil is from serial application and with optimized additive packages, thus especially containing detergent and dispersant additives [40].

\begin{tabular}{lllll} 
Table 2 & Load stages step test $(\mathrm{LSE} / \mathrm{LS} 1 \ldots$ 14) \\
\hline $\begin{array}{l}\text { Load } \\
\text { stage }\end{array}$ & Cycles & $\begin{array}{l}\text { Pressure } \\
\mathrm{p} / \mathrm{N} / \mathrm{mm}^{2}\end{array}$ & $\begin{array}{l}\text { Sliding velocity } \\
\mathrm{v}_{\mathrm{g}, \mathrm{max}} / \mathrm{m} / \mathrm{s}\end{array}$ & $\begin{array}{l}\text { Spec. friction } \\
\text { work } \\
\mathrm{q} / \mathrm{J} / \mathrm{mm}^{2}\end{array}$ \\
\hline LSE & 500 & 0.5 & 15 & 0.25 \\
LS1 & 10 & $0.65 / 1.0 / 2.5$ & 17 & 0.33 \\
LS2 & 10 & $0.65 / 1.0 / 2.5$ & 21 & 0.50 \\
LS3 & 10 & $0.65 / 1.0 / 2.5$ & 25 & 0.70 \\
LS4 & 10 & $0.65 / 1.0 / 2.5$ & 28 & 0.94 \\
LS5 & 10 & $0.65 / 1.0 / 2.5$ & 32 & 1.22 \\
LS6 & 10 & $0.65 / 1.0 / 2.5$ & 36 & 1.53 \\
LS7 & 10 & $0.65 / 1.0 / 2.5$ & 40 & 1.87 \\
LS8 & 10 & $0.65 / 1.0 / 2.5$ & 44 & 2.25 \\
LS9 & 10 & $0.65 / 1.0 / 2.5$ & 48 & 2.66 \\
LS10 & 10 & $0.65 / 1.0 / 2.5$ & 52 & 3.11 \\
LS11 & 10 & $0.65 / 1.0 / 2.5$ & 55 & 3.60 \\
LS12 & 10 & $0.65 / 1.0 / 2.5$ & 59 & 4.12 \\
LS13 & 10 & $0.65 / 1.0 / 2.5$ & 63 & 4.67 \\
LS14 & 10 & $0.65 / 1.0 / 2.5$ & 67 & 5.26 \\
\hline
\end{tabular}

\subsection{Test procedure}

The test procedure is based on the work of Hensel, Strebel and Schneider [1, 35, 43], who suggested step tests for the investigation of spontaneous damage behavior of wet clutches. Fig. 2 visualizes the test procedure. We started with running-in cycles to eliminate non-linear effects that only occur in the first engagements [44, 45]. For the running-in, we used the well-established (non-damaging) specific loads from prior research on friction behavior of the same friction linings [40].

After running-in, the actual step test began. Starting with load stage 1 (see Table 2), 10 cycles were performed for each load stage. For one step test, all load stages were run at a constant pressure. According to Schneider, 10 cycles are an ideal trade-off between the exclusion of long-term effects and reliable spontaneous damage detection despite stochastic influences [46]. The cycle time between two engagements was increased with each load stage to ensure the cooling of the plates to approximate oil injection temperature before the next engagement. The specific oil flow was $0.8 \mathrm{~mm}^{3} / \mathrm{mm}^{2} \mathrm{~s}$ and oil was injected at $80^{\circ} \mathrm{C}$ into the inner carrier of the clutch.

After 10 cycles of one load stage, the clutch was removed from the test rig and both the steel plates and the friction plates were checked for visible damage. The result of visual assessment is documented in the friction work/ friction power diagram (see Fig. 3).

The step test continued subsequently with the next load stage (at the same pressure level). In order to compensate the single-sided thermal load on the outer steel plates, they were turned after each inspection. The specific loads (fric- 


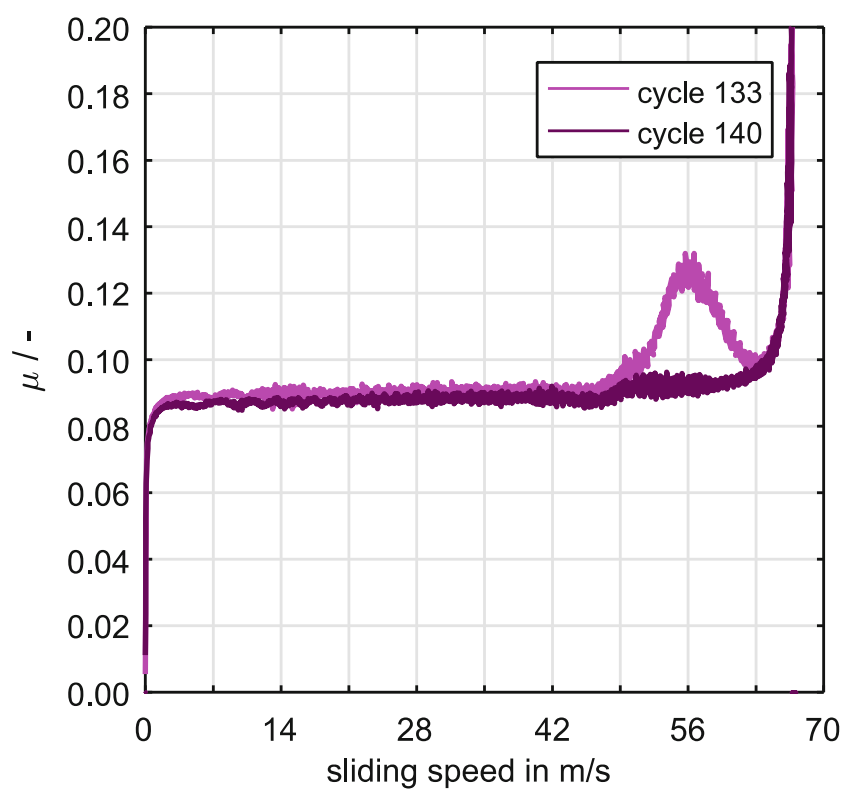

Fig. $4 \mu$-v-curve of test RS-06-recovery of friction characteristic LS14 $\left(p=1 \mathrm{~N} / \mathrm{mm}^{2}, \mathrm{q}=5.26 \mathrm{~J} / \mathrm{mm}^{2}, \mathrm{v}_{\mathrm{g}}=67 \mathrm{~m} / \mathrm{s}\right), \mathrm{C} / \mathrm{C}, \mathrm{sp} 3.5 \mathrm{~mm}$

tion work and sliding speed) were continuously increased (see Table 2). The step test ended when the clutch reached load stage 14 or if the clutch failed prematurely due to spontaneous damage. All specific data with respect to gross friction surface was normalized.

We ran 16 tests with 16 clutch packages (three different pressures, one repetition test for each variant). In each variant, we varied friction lining and/or steel plate thickness (2 different steel plate thicknesses (sp $3.5 \mathrm{~mm}$ and $6 \mathrm{~mm}$ ) and two different friction linings CFRP and C/C). specific nominal friction work is plotted over the specific nominal friction power (assumption $\mu=$ const. $=0.11$ ). Each point in the diagram represents one load stage (LS1 ... 14) of the step test. The diagram differentiates between non-damaging and damaging load stages. Furthermore, it documents results of the visual assessments and changes in friction behavior. The classification in each load stage is based on the plate which shows the most significant appearance. Fig. 3 explains the comparison of visual assessments and deterioration classification from visual assessments and friction behavior.

Based on the findings of the experimental investigations, we distinguish between the four classification categories of "no indication", "change in color", "unsteady friction behavior" and "deterioration of friction lining".

In contrast to the category "hot spots" [31-35], which is frequently found in literature, the category "change in color" is used in this publication as long as the change in color of the plates does not permanently affect friction behavior. As soon as we identify clear influences on friction behavior at the end of a load stage, we use the category "unsteady friction behavior".

Fig. 4 illustrates the recovery of friction-characteristic $(\mu-$ v-curve), which we observed especially with $\mathrm{C} / \mathrm{C}$ friction linings. We see a peak in the $\mu-v$-curve at the beginning of the first few cycles (cycle 3 in LS14) of a new load stage. This peak disappears after a few cycles (cycle 10 in LS14). We therefore classify this behavior as "change in color". The category "unsteady friction behavior" seems to be inaccurate because the friction behavior at the end of the load stage cannot be characterized as unsteady.

\subsection{Evaluation method}

The evaluation of the step tests is based on deterioration classification in friction work/friction power diagrams (see Fig. 3). In a friction work over friction power diagram, the

Fig. 5 Trend plot RS-7, $p=0.65 \mathrm{~N} / \mathrm{mm}^{2},(\mathrm{C} / \mathrm{C}, \mathrm{sp}$ $3.5 \mathrm{~mm}$ ), ended without failure
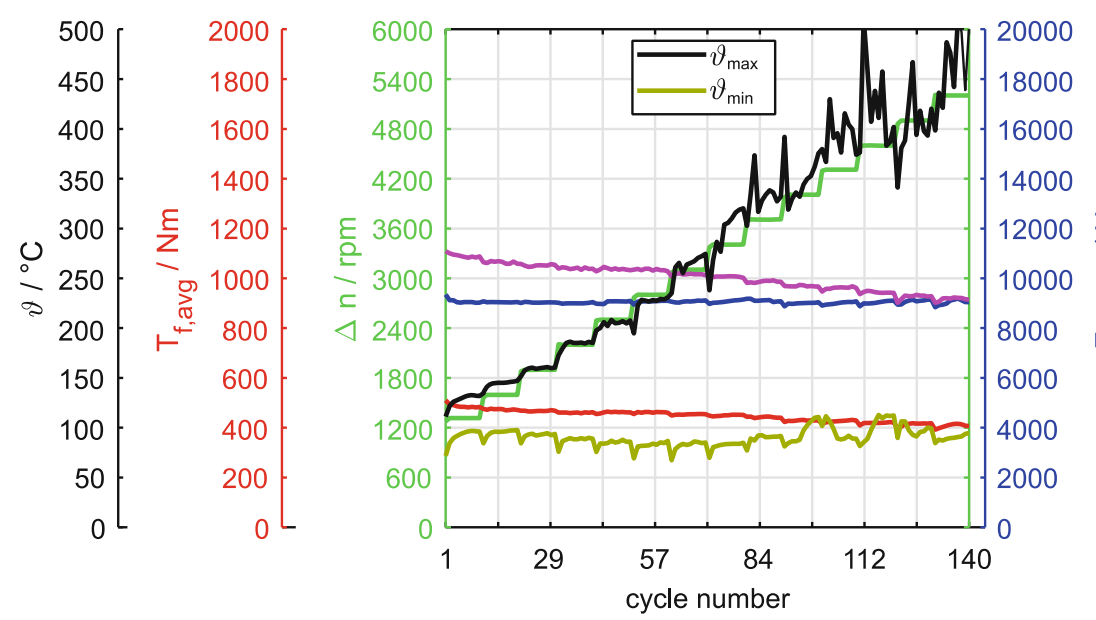

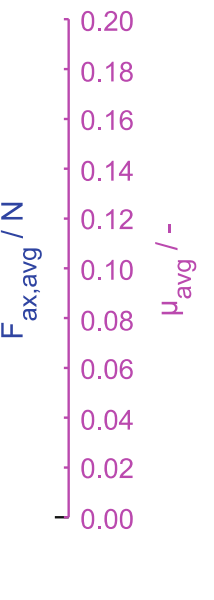


Fig. 6 Trend plot RS-12, $p=0.65 \mathrm{~N} / \mathrm{mm}^{2}$, (CFRP, sp $3.5 \mathrm{~mm}$ ), ended in LS10
Fig. 7 Reproducibility RS-19 (first run) vs RS-20 (repro), C/C, sp $6 \mathrm{~mm}, p=0.65 \mathrm{~N} / \mathrm{mm}^{2}$
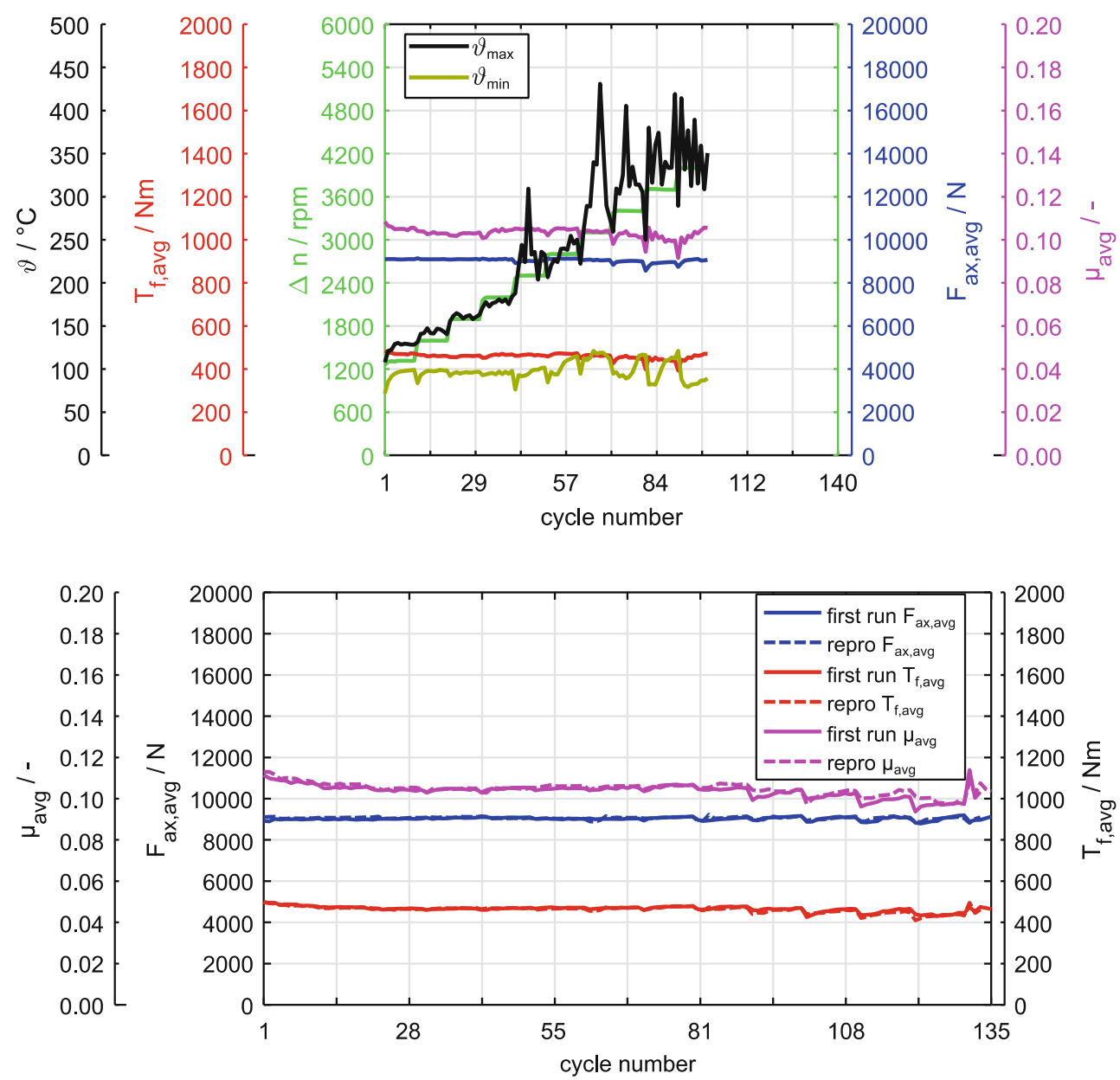

3 Results and discussion

\subsection{Exemplary trend plots}

Fig. 5 and 6 show the trend plots (specific values for each cycle) of two different friction linings during the step test with $p=0.65 \mathrm{~N} / \mathrm{mm}^{2}$. The figures show the min. and max. temperatures in the steel plates $\left(\vartheta_{\max , \min }\right)$, the maximum differential speed $(\Delta \mathrm{n})$ and the averaged values for every cycle of friction torque $\left(\mathrm{T}_{\mathrm{f}, \mathrm{avg}}\right)$, axial load $\mathrm{F}_{\mathrm{ax}, \text { avg }}$ and Coefficient of Friction $(\mathrm{CoF})\left(\mu_{\mathrm{avg}}\right)$.

The average $\mathrm{CoF}$ of the $\mathrm{C} / \mathrm{C}$ friction lining slightly decreases at higher loads, whereas the CoF of the CFRP friction lining stays almost constant until failure in load stage LS10. The temperature signal $\vartheta_{\text {min }}$ indicates that the cycle time for the tests is sufficiently long to keep the minimum temperature close to the oil injection temperature before the next engagement. The fluctuations of signal $\vartheta_{\max }$ at high load stages are probably due to non-uniform pressure contribution caused by high thermal loads leading to high/low pressure close to the thermocouple drill hole.

The tests with the $\mathrm{C} / \mathrm{C}$ friction lining (e.g. Fig. 5) ended after LS14 without failure. The system could operate prop- 
Table 3 Reproducibility of failure in step tests

\begin{tabular}{|c|c|c|c|c|c|}
\hline Test & Setup & $\begin{array}{l}\text { No } \\
\text { indi- } \\
\text { cation }\end{array}$ & $\begin{array}{l}\text { Change } \\
\text { in } \\
\text { color }\end{array}$ & $\begin{array}{l}\text { Unsteady } \\
\text { friction } \\
\text { behavior }\end{array}$ & $\begin{array}{l}\text { Deteriora- } \\
\text { tion of } \\
\text { friction } \\
\text { lining }\end{array}$ \\
\hline $\begin{array}{l}\mathrm{C} / \mathrm{C} \\
\text { (RS-7) }\end{array}$ & $\begin{array}{l}p= \\
0.65 \mathrm{~N} / \mathrm{mm}^{2}\end{array}$ & - & $\mathrm{LS} 14^{\mathrm{a}}$ & - & - \\
\hline $\begin{array}{l}\mathrm{C} / \mathrm{C} \\
\text { repro } \\
(\mathrm{RS}-8)\end{array}$ & $\begin{array}{l}\mathrm{sp} \\
3.5 \mathrm{~mm}\end{array}$ & - & $\mathrm{LS} 14^{\mathrm{a}}$ & - & - \\
\hline $\begin{array}{l}\mathrm{C} / \mathrm{C} \\
\text { (RS- } \\
19)\end{array}$ & $\begin{array}{l}p= \\
0.65 \mathrm{~N} / \mathrm{mm}^{2} \\
\mathrm{sp}\end{array}$ & - & - & - & LS14 \\
\hline $\begin{array}{l}\mathrm{C} / \mathrm{C} \\
\text { repro } \\
\text { (RS- } \\
20)\end{array}$ & $6.0 \mathrm{~mm}$ & - & - & - & LS14 \\
\hline $\begin{array}{l}\text { CFRP } \\
(\mathrm{RS}- \\
10)\end{array}$ & $\begin{array}{l}p= \\
1.0 \mathrm{~N} / \mathrm{mm}^{2} \\
\mathrm{sp}\end{array}$ & - & - & LS6 & - \\
\hline $\begin{array}{l}\text { CFRP } \\
\text { repro } \\
\text { (RS- } \\
11)\end{array}$ & $3.5 \mathrm{~mm}$ & - & - & LS8 & - \\
\hline $\begin{array}{l}\text { CFRP } \\
\text { (RS- } \\
23)\end{array}$ & $\begin{array}{l}p= \\
0.65 \mathrm{~N} / \mathrm{mm}^{2} \\
\mathrm{sp}\end{array}$ & - & - & - & LS9 \\
\hline $\begin{array}{l}\text { CFRP } \\
\text { repro } \\
\text { (RS- } \\
24)\end{array}$ & $6.0 \mathrm{~mm}$ & - & - & LS9 & - \\
\hline
\end{tabular}

a Test ended without failure

erly at temperatures up to $500^{\circ} \mathrm{C}$ in the center of the steel plates.

\subsection{Reproducibility}

One test was reproduced for each variant with a new clutch package. The average $\mathrm{CoF}$ and the mean torque of all tests correlate well with their repro tests. As an example, Fig. 7 illustrates excellent reproducibility of measurements by comparing axial force (blue), friction torque (red) and CoF (magenta) from the first run (RS19 full line) and the repro run (RS20 dashed line). The average CoF slightly decreases for both tests within the first two load stages and remains constant till LS9. The CoF further decreases subsequently until about 0.1 , due to very severe loads.

Table 3 compares results from test and repro tests and summarizes the load stages in which the different clutch packages finally failed. In LS3 ...5, the first changes in color on the steel plates of all tests occurred, which did not influence friction behavior in the first load stages. In higher load stages, especially in the first few cycles, friction behavior sometimes became unsteady. When friction behavior had improved within the 10 cycles of a load stage, the test was not ended due to "unsteady friction behavior" (see Fig. 4).

For RS7/8 (C/C, sp $3.5 \mathrm{~mm})$, the friction behavior was unsteady starting in LS10 at the beginning of a new load stage, but became smooth again within the next cycles of each load stage. This is why the tests were not rated as "unsteady friction behavior". Both tests ended without failure after LS14.

RS-19 and RS-20 both failed because the friction lining in the last load stage LS14 had deteriorated. Small discontinuities in friction behavior were observed from LS8/9 on, which improved during the cycles in each load stage.

Reproducibility of RS-10 and RS-11 were not as good as that of the other tests. Plates of RS-10 were not turned after each visual assessment, which possibly explains differences between RS-10 and RS-11. Thus, buckling of the first and last steel plate of the package, probably caused by singlesided thermal load, led to unsteady friction behavior earlier in test RS-10 than in RS-11.

RS-24 was ended after 6 cycles in LS9, since friction behavior had already significantly worsened. A deterioration of the friction lining in a few more cycles is very likely, as observed in RS-23, which was run until cycle 10 of LS9.

The reproducibility of the test results is good. Small differences can be attributed to the procedure. Some tests were ended before complete failure of the parts (deterioration of friction lining) to prevent damage to the test rig.

\subsection{Comparison of different variants}

To compare the four different variants, we focused on the load stage where the clutch failed or the test was ended. All clutch packages with $6 \mathrm{~mm}$ steel plates failed because the friction lining had deteriorated.

The C/C (sp $3.5 \mathrm{~mm})$ reached LS14 without failure for $p=0.65 \mathrm{~N} / \mathrm{mm}^{2}$ and $1.0 \mathrm{~N} / \mathrm{mm}^{2}$. The third test $(\mathrm{C} / \mathrm{C}$, sp $3.5 \mathrm{~mm}, p=2.5 \mathrm{~N} / \mathrm{mm}^{2}$ ) was ended due to unsteady friction behavior in LS10. Using CFRP and $3.5 \mathrm{~mm}$ steel plates, the tests with $p=0.65 \mathrm{~N} / \mathrm{mm}^{2}$ and $p=2.5 \mathrm{~N} / \mathrm{mm}^{2}$ failed due to deterioration of the friction lining; the test with $p=1 \mathrm{~N} / \mathrm{mm}^{2}$ was ended because of unsteady friction behavior.

Fig. 8 presents the load stages in which the 12 tests failed or were ended. The compensation curves are calculated from 3 tests of one variant according to the equation developed by Strebel $[35,43]$. The compensation curve of $\mathrm{C} / \mathrm{C}(\mathrm{sp} 3.5 \mathrm{~mm}$ ) does not strictly follow the definition of Strebel, because two tests were ended in LS14 without failure. The test conditions where failure occurred were very severe. The performance of the $\mathrm{C} / \mathrm{C}$ friction lining is significantly better than that of the CFRP friction lining, both for the $3.5 \mathrm{~mm}$ and the $6 \mathrm{~mm}$ steel plates. The influence of steel plate thickness cannot be clearly identified. When $p=2.5 \mathrm{~N} / \mathrm{mm}^{2}$, tests with the $6 \mathrm{~mm}$ steel plate, both for C/C 
Fig. 9 Visual assessment of steel and friction plates after comparable load stages

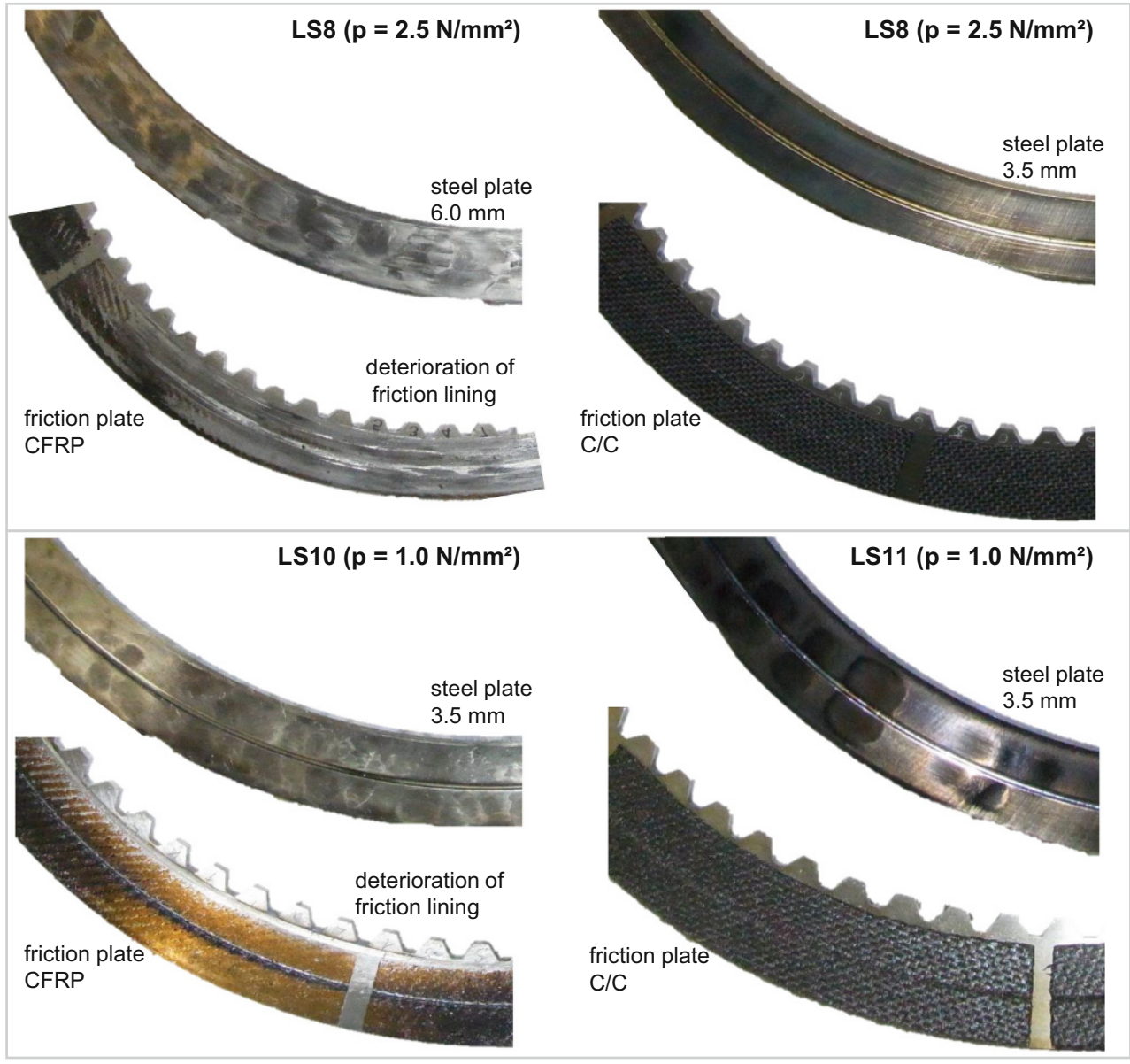

and CFRP, failed in higher load stages. For $p=1.0 \mathrm{~N} / \mathrm{mm}^{2}$, the test with the thicker steel plates reached a higher load stage for the CFRP friction lining, but a lower load stage for the $\mathrm{C} / \mathrm{C}$ friction lining. At low pressure $\left(p=0.65 \mathrm{~N} / \mathrm{mm}^{2}\right)$, the CFRP (sp $3.5 \mathrm{~mm}$ ) reached a higher load stage. In LS14, the test with the $\mathrm{C} / \mathrm{C}$ ( $\mathrm{sp} 3.5 \mathrm{~mm}$ ) was ended without failure of the clutch, whereas the test with the $6 \mathrm{~mm}$ steel plates ended because of deterioration of the friction lining in this load stage.

Fig. 9 presents results from the visual assessments of the steel and friction plates after a certain load stage. In LS8, the $\mathrm{C} / \mathrm{C}$ friction lining did not show any damage compared to the CFRP friction lining, which was completely deteriorated. Furthermore, the steel plates of the $\mathrm{C} / \mathrm{C}$ friction lining are in a much better condition than the ones that were used with the CFRP friction lining.

At lower pressures, both tests reached higher load stages before failure. After load stage 10, the CFRP was highly deteriorated and the mating steel plates had changed color. The steel plates in LS11 that were used with the C/C friction lining changed color as well, but the friction lining had not deteriorated.
The performance of all variants during the tests was very good. Especially the very high performance of the $\mathrm{C} / \mathrm{C}$ friction lining had never been published before. The specific energy of $5.26 \mathrm{~J} / \mathrm{mm}^{2}$ in combination with a sliding velocity of $67 \mathrm{~m} / \mathrm{s}$ shows extremely severe load conditions. We expect to obtain even higher loads than presented, especially for the CFRP friction lining, when the setup in the test rig is optimized such that the heat input in all steel plates is symmetric to avoid buckling of the outer plates.

\section{Outlook and conclusion}

In 16 step tests, the endurance life towards spontaneous damage was investigated for woven CFRP and C/C friction linings. In addition the influence of different steel plate thicknesses was analyzed. Although the friction behavior at low loads was comparable for the CFRP and the C/C friction linings, we identified significant differences in the results of spontaneous damage tests.

The endurance limit of the CFRP friction lining against spontaneous damage was identified at levels of a specific energy up to $2.66 \mathrm{~J} / \mathrm{mm}^{2}$ in combination with sliding veloc- 
ities of up to $48 \mathrm{~m} / \mathrm{s}$. The $\mathrm{C} / \mathrm{C}$ friction lining passed LS14 $\left(\mathrm{q}=5.26 \mathrm{~J} / \mathrm{mm}^{2}, \mathrm{v}_{\mathrm{g}}=67 \mathrm{~m} / \mathrm{s}\right)$. This is the highest published spontaneous damage resistance for wet clutches. Even at mass temperatures of about $500^{\circ} \mathrm{C}$, the clutch package still operated properly.

Compared with published results of other clutches, all variants showed excellent performances and thus are suitable for high-performance applications. However, the endurance of the $\mathrm{C} / \mathrm{C}$ friction lining against spontaneous damage was considerably better than that of the CFRP friction lining. The influence of thicker steel plates on spontaneous damage could not be proofed clearly.

Further research should extend the knowledge about high performance Carbon friction linings like CFRP and C/C. Furthermore, the elimination of single-sided thermal loads on the outer plates could improve the performance of CFRP and $\mathrm{C} / \mathrm{C}$ friction linings even more.

Funding Open Access funding enabled and organized by Projekt DEAL.

Conflict of interest The authors D. Groetsch, U. Stockinger, T. Schneider, F. Reiner, K. Voelkel, H. Pflaum and K. Stahl would like to thank SGL Technologies $\mathrm{GmbH}$ for supporting and providing the test parts.

Open Access This article is licensed under a Creative Commons Attribution 4.0 International License, which permits use, sharing, adaptation, distribution and reproduction in any medium or format, as long as you give appropriate credit to the original author(s) and the source, provide a link to the Creative Commons licence, and indicate if changes were made. The images or other third party material in this article are included in the article's Creative Commons licence, unless indicated otherwise in a credit line to the material. If material is not included in the article's Creative Commons licence and your intended use is not permitted by statutory regulation or exceeds the permitted use, you will need to obtain permission directly from the copyright holder. To view a copy of this licence, visit http://creativecommons.org/licenses/by/4. $0 /$.

\section{References}

1. Hensel M (2014) Thermische Beanspruchbarkeit und Lebensdauerverhalten von nasslaufenden Lamellenkupplungen. Dissertation, Technische Universität München

2. Wang Q, Zhang X, Pei X et al (2010) Friction and wear properties of solid lubricants filled/carbon fabric reinforced phenolic composites. J Appl Polym Sci 117:2480-2485. https://doi.org/10.1002/app. 32154

3. Vigneshkumar S, Rajasekaran T (2018) Experimental analysis on tribological behavior of fiber reinforced composites. IOP Conf Ser Mater Sci Eng 402:12198. https://doi.org/10.1088/1757-899X/402/ $1 / 012198$

4. Rank R, Kearsey A (2004) Carbon based friction materials for automotive applications. In: 14th International Colloquium Tribology, pp 471-476

5. Föge V, Eder M, Nickel F (2015) Innovation von Fiber Composite Reibsystemen - Von der Faser bis zur Anwendung. In: VDI (ed) Kupplungen und Kupplungssysteme in Antrieben, pp 185-196

6. Wenbin L, Jianfeng H, Jie F et al (2015) Simulation of the engagement of carbon fabric wet clutch: Analytical and experimen- tal comparison. Tribol Int 90:502-508. https://doi.org/10.1016/j. triboint.2015.05.018

7. Ahmadijokani F, Shojaei A, Arjmand M et al (2019) Effect of short carbon fiber on thermal, mechanical and tribological behavior of phenolic-based brake friction materials. Compos Part B Eng 168:98-105. https://doi.org/10.1016/j.compositesb.2018.12.038

8. Fei J, Li W, Huang J et al (2016) Variation of the tribological properties of carbon fabric composites in their whole service life. Tribol Int 99:29-37. https://doi.org/10.1016/j.triboint.2016.03.006

9. Wenbin L, Jianfeng H, Jie F et al (2016) Study on tribological properties as a function of operating conditions for carbon fabric wet clutch. Tribol Int 94:428-436. https://doi.org/10.1016/j.triboint. 2015.10.015

10. Satapathy BK, Bijwe J (2006) Composite friction materials based on organic fibres: Sensitivity of friction and wear to operating variables. Compos Part A Appl Sci Manuf 37:1557-1567. https://doi. org/10.1016/j.compositesa.2005.11.002

11. Kearsey A, Wagner D (1997) Carbon fiber for wet friction applications. SAE technical paper, vol 972754. https://doi.org/10.4271/ 972754

12. Stockinger U, Pflaum H, Stahl K (2018) Zeiteffiziente Methodik zur Ermittlung des Reibungsverhaltens nasslaufender Lamellenkupplungen mit Carbon-Reibbelag. Forsch Ingenieurwes. https://doi. org/10.1007/s10010-017-0253-X

13. Cheng Y-C, Wu C-M, Lin P-C et al (2020) Friction behaviors of staple carbon fiber composites. Mod Phys Lett B 34:2040002. https:// doi.org/10.1142/S0217984920400023

14. Fei J, Wang H-K, Huang J-F et al (2014) Effects of carbon fiber length on the tribological properties of paper-based friction materials. Tribol Int 72:179-186. https://doi.org/10.1016/j.triboint.2013. 12.017

15. Wu C-M, Cheng Y-C, Lai W-Y et al (2020) Friction and wear performance of staple carbon fabric-reinforced composites: Effects of surface topography. Polymers (Basel). https://doi.org/10.3390/ polym 12010141

16. Zhang Z-Z, Su F-H, Wang K et al (2005) Study on the friction and wear properties of carbon fabric composites reinforced with microand nano-particles. Mater Sci Eng A 404:251-258. https://doi.org/ 10.1016/j.msea.2005.05.084

17. Su F-H, Zhang Z-Z, Liu W-M (2006) Mechanical and tribological properties of carbon fabric composites filled with several nano-particulates. Wear 260:861-868. https://doi.org/10.1016/j.wear.2005. 04.015

18. Wang B, Fu Q, Li H et al (2019) Synergistic effect of surface modification of carbon fabrics and multiwall carbon nanotube incorporation for improving tribological properties of carbon fabrics/resin compositestribological properties of carbon fabrics/resin composites. Polym Compos 41:102-111. https://doi.org/10.1002/pc.25349

19. Wang W-J, Huang J-F, W-b L et al (2015) The influence of added carbon nanotubes on the properties of the carbon-fiber-reinforced paper-based wet clutch friction materials. Lubr Sci 27:451-461. https://doi.org/10.1002/ls. 1298

20. Wenbin L, Jianfeng H, Jie F et al (2016) A novel preparation approach for improving the mechanical and wet tribological properties of carbon fabric/phenolic composites. Mater Des 103:356-364. https://doi.org/10.1016/j.matdes.2016.04.077

21. Fei J, Li H-J, Huang J-F et al (2012) Study on the friction and wear performance of carbon fabric/phenolic composites under oil lubricated conditions. Tribol Int 56:30-37. https://doi.org/10.1016/ j.triboint.2012.06.022

22. Fei J, Luo W, Huang JF et al (2015) Effect of carbon fiber content on the friction and wear performance of paper-based friction materials. Tribol Int 87:91-97. https://doi.org/10.1016/j.triboint.2015.02.019

23. Gibson DW, Taccini CJ (1989) Carbon/carbon friction materials for dry and wet brake and clutch applications. SAE technical paper series. SAE International, Warrendale 
24. Luo W, Liu Q, Li Y et al (2016) Enhanced mechanical and tribological properties in polyphenylene sulfide/polytetrafluoroethylene composites reinforced by short carbon fiber. Compos Part B Eng 91:579-588. https://doi.org/10.1002/app.46269

25. Oldfield RC, Watts RF (2006) Impact of lubricant formulation on the friction properties of carbon fiber clutch plates. Lubr Sci. https:// doi.org/10.1002/ls.4

26. Wang H, Qi X, Zhang W et al (2020) Tribological properties of PTFE/Kevlar fabric composites under heavy loading. Tribol Int 151:106507. https://doi.org/10.1016/j.triboint.2020.106507

27. Acuner R, Pflaum H, Stahl K (2016) Tribologische Schädigungsmechanismen von Synchronisierungen mit Carbon-Reibwerkstoffen. In: FVA (ed) GETLUB - Tribologie- und Schmierstoffkongress, pp 239-251

28. Stockinger U, Schneider T, Pflaum H et al (2020) Single vs. multicone synchronizers with carbon friction lining-A comparison of load limits and deterioration behavior. Forsch Ingenieurwes 214:55. https://doi.org/10.1007/s10010-020-00406-1

29. Osanai H, Ikeda K, Kato K (1990) Relations between temperature in friction surface and degradation of friction materials during engaging of wet friction paper. SAE technical paper series. SAE International, Warrendale

30. Maeda M, Murakami Y (2003) Testing method and effect of ATF performance on degradation of wet friction materials. SAE technical paper series. SAE International, Warrendale

31. Kasem H, Brunel JF, Dufrénoy P et al (2011) Thermal levels and subsurface damage induced by the occurrence of hot spots during high-energy braking. Wear 270:355-364. https://doi.org/10.1016/j. wear.2010.11.007

32. Hämmerl B (1995) Lebensdauer-und Temperaturverhalten ölgekühlter Lamellenkupplungen bei Lastkollektivbeanspruchung. Dissertation, Technische Universität München

33. Anderson AE, Knapp RA (1990) Hot spotting in automotive friction systems. Wear 135:319-337. https://doi.org/10.1016/00431648(90)90034-8

34. Fairbank D, Maruo K, Du S et al (2001) ATF additive effects on hot spot formation in wet clutches. In: International Fall Fuels and Lubricants Meeting and Exposition; San Antonio, TX; United States; 24 September. SAE Technical Paper Series. https://doi.org/10.4271/ 2001-01-3594
35. Schneider T, Strebel M, Pflaum H et al (2019) Spontanschädigungsverhalten von nasslaufenden Lamellenkupplungen mit organischen und metallischen Reibbelägen. Forsch Ingenieurwes 83:199-207. https://doi.org/10.1007/s10010-019-00304-1

36. Eleöd A, Oucherif F, Devecz J et al (1999) Conception of numerical and experimental tools for study of the Tribological Transformation of Surface (TTS). In: Lubrication at the frontier-The role of the interface and surface layers in the thin film and boundary regime. Proceedings of the 25th Leeds-Lyon Symposium on Tribology, vol 36. Elsevier, Amsterdam, pp 673-682

37. Antoni G (2014) A phenomenological modelling with thermo-mechanical coupling for Tribological Surface Transformations (TSTs). Int J Eng Sci 78:218-232

38. Antoni G, Désoyer T, Lebon F (2012) A combined thermo-mechanical model for tribological surface transformations. Mech Mater 49:92-99. https://doi.org/10.1016/j.mechmat.2011.12.005

39. Lam RC, Chavdar B, Newcomb T (2006) New generation friction materials and technologies

40. Stockinger U, Groetsch D, Pflaum H et al (2021) Friction behavior of innovative carbon friction linings for wet multi-plate clutches. Forsch Ingenieurwes. https://doi.org/10.1007/s10010-020-00436-9

41. Meingaßner GJ, Pflaum H, Stahl K (2015) Test-rig based evaluation of performance data of wet disk clutches. In: 14th International CTI Symposium

42. Polifke W, Kopitz J (2009) Wärmeübertragung: Grundlagen, analytische und numerische Methoden, 2nd edn. Always learning. Pearson, München

43. Strebel M (2017) Spontanschäden an nasslaufenden Lamellenkupplungen. Dissertation, Technische Universität München

44. Voelkel K, Pflaum H, Stahl K (2020) Running-in behavior of wet multi-plate clutches: introduction of a new test method for investigation and characterization. Chin J Mech Eng 33:1461. https://doi. org/10.1186/s10033-020-00450-6

45. Voelkel K, Pflaum H, Stahl K (2019) Einflüsse der Stahllamelle auf das Einlaufverhalten von Lamellenkupplungen. Forsch Ingenieurwes 28:2148. https://doi.org/10.1007/s10010-019-00303-2

46. Schneider T, Voelkel K, Pflaum H et al (2020) Friction behavior of pre-damaged wet-running multi-plate clutches in an endurance test. Lubricants 8:68. https://doi.org/10.3390/lubricants8070068 